\title{
Exploration and Practice of the Integration of Specialty Education and Innovation and Entrepreneurship Education in Colleges and Universities in Transition and Development
}

\author{
Wei Li, Xiaochu Wang, Jia Yang, Yunhan Li \\ Shenyang University \\ Liaoning, Shenyang, 110044, China
}

\begin{abstract}
With the transformation of China's economic development mode and the acceleration of the transformation and the upgrading of industrial structure, college students with the quality and ability of innovation and entrepreneurship have been paid more and more attention by society. As a new way of talent cultivation, innovation and entrepreneurship education has gradually become the focus of education and teaching reform in colleges and universities is needed. This article will combine the exploration and practice of the integration of Road and Bridge professional education and innovation and entrepreneurship education training mode with the School of Architecture and Engineering of Shenyang University, focusing on the construction of the "one lesson, two blends" system, seeking the effective integration measures of Road and Bridge professional education and innovation and entrepreneurship education, in order to provide relevant experience for the development of colleges and universities in transition.
\end{abstract}

Keywords-transformation and development; professional education; innovation and entrepreneurship education; education integration

\section{INTRODUCTION}

"Mass entrepreneurship and innovation," and "Internet+" have brought great challenges to the innovative thinking of Road and Bridge students. It is also an important issue to explore ways to integrate innovation and entrepreneurship education with Road and Bridge education. It is a new content of the transformation and development of Chinese universities and the development of modern university education to change the single target orientation of professional talents and innovate the training mode of talents [1].

Innovation and entrepreneurship education as a new way of personnel training has gradually become the focus of higher education reform. In order to effectively enhance the innovation and entrepreneurship ability of college students, colleges and universities need to integrate innovation and entrepreneurship education into talent training programs, and form a new pattern of innovation education of "trinity" of the first classroom, the second classroom and internship training base inside and outside the school. However, for most universities in China, the status quo that innovation and entrepreneurship education is still outside the professional curriculum system (commonly known as "the first classroom") remains unchanged[2], but also in "the second class" that offers elective courses, lectures or business plan competitions in entrepreneurship. Even though a few colleges and universities have incorporated entrepreneurship education into their discipline construction plans, there are still many irrational phenomena in the curriculum, lack of integrity, systematicness and cohesion. The main problem of innovation and entrepreneurship education in colleges and universities is that innovation and entrepreneurship education and professional education wear their own shoes, and the phenomenon of going their own way is still very common.

This paper will focus on the integration of Road and Bridge professional education and innovation and entrepreneurship education on the exploration and practice, focusing on the integration of effective measures, in order to provide relevant experience for the transformation and development of engineering majors in colleges and universities.

\section{CURRENT SitUATION AND PROBLEMS OF INNOVATION AND ENTREPRENEURSHIP EDUCATION IN ROAD AND BRIDGE SPECIALTY}

In order to better carry out innovation and entrepreneurship education, Shenyang University established the Innovation and Entrepreneurship Guidance Center for College Students in 2014. It has carried out innovation and entrepreneurship education in an all-round way in the whole school, which has been incorporated into the personnel training program, and innovation credits have been increased. Innovation Course and Entrepreneurship Course have been set up as two required courses for general education. Each student can also obtain more innovation credits by participating in large-scale innovation projects, skills competitions and individualized courses on innovation and entrepreneurship organized by schools and colleges. In the school-wide range a wave of learning innovation and entrepreneurship has set off. But after more than four years of operation, most students are 
still subjectively seeking innovative credits of up to six credits. In order to graduate smoothly and participate in some innovation and entrepreneurship competitions which have little connection with this major, the innovation and entrepreneurship education in our university is just dissociated from the professional curriculum system without realizing the importance of innovation and entrepreneurship fundamentally. There are still some problems, such as the lack of integration and close relationship between innovation and entrepreneurship education and professional education, which makes innovation and entrepreneurship education become "the second classroom" out of touch with professional education[35].

In our view, innovation and entrepreneurship education should be based on college students' professional education. The idea of entrepreneurship education should be incorporated into the professional education, and the innovation and entrepreneurship should be based on the professional content, which is the main principle that entrepreneurship education must grasp for the college students who take knowledge and skills as the main venture capital.

The goal of the Road and Bridge Engineering major is to train senior engineering and technical talents who master the basic theories and basic knowledge of engineering mechanics and engineering structure, and who are capable of project planning, design, research and development, construction and management of Road and Bridge Engineering and who can engage in technical or management work. Under the background of the transformation and development of colleges and universities, deepening the reform of the teaching content of Road and Bridge Engineering, and actively exploring ways and means of integrating Road and Bridge Engineering and innovation and entrepreneurship education are important topics in front of Road and Bridge Engineering educators. As an effective tool to cultivate college students' innovative and entrepreneurial literacy, innovation and entrepreneurship education are also the trend of the times. With the rise of "Mass entrepreneurship and innovation," and "Internet+" thinking as a national strategy, coupled with the grim employment situation, the enthusiasm for innovation and entrepreneurship of college students in the school road bridge engineering continues to rise. However, behind the enthusiasm for innovation and entrepreneurship, it is the one-sided understanding and cognition of college students majoring in Road and Bridge Engineering.

We believe that it is urgent to actively explore the way of integration of Road and Bridge Engineering professional education and innovation and entrepreneurship education to solve the phenomenon of disconnection between innovation and entrepreneurship education and professional education. The construction of "one lesson, two blends" system of Road and Bridge Engineering education and innovation and entrepreneurship education has become the top priority[6].

The cultivation of professional accomplishment and the acquisition of professional skills of the undergraduates majoring in Road and Bridge Engineering mainly depend on the daily study of the courses of Road and Bridge Engineering. If "the first classroom" of Road and Bridge Engineering education and "the second classroom" of innovation and entrepreneurship education can not be effectively integrated. In the long run, it will have a negative impact on college students' professional knowledge learning and the healthy development of Road and Bridge Engineering major. On the contrary, if innovation and entrepreneurship education can be integrated into Road and Bridge Engineering education timely and scientifically, it will not exclude Road and Bridge Engineering education, but also make innovation and entrepreneurship education more in-depth and more closely dependent on Road and Bridge Engineering education. From the national perspective, the integration of Road and Bridge Engineering education and innovation and entrepreneurship education is still in the exploratory stage.

\section{THE GOAL OF EDUCATION REFORM}

Integrate school resources, starting from the integration of Road and Bridge professional education and innovation and entrepreneurship education, focusing on the combination of "solid foundation" and "skillful skills". Strengthen students' practical ability, innovation and entrepreneurial ability and other comprehensive abilities, the theory and practice, scientific research and teaching, in-class and out-of-class, knowledge learning and quality development, innovation awareness training and practical ability to enhance the organic combination, reorganization of teaching content, optimization of the curriculum system, to achieve the "comprehensive" of the curriculum system.

Establish the "three mechanisms" teaching mode reform of "one lesson, two blends", and perfect the cooperation mechanism with enterprises. Carry out young teachers' "inpost" practice and strengthen the construction of "doublequalified and double-capable" teaching staff. Revise the professional personnel training plan of the integration of Road and Bridge major and innovation and entrepreneurship education, and construct the modular curriculum system of the organic integration of innovation and entrepreneurship education and professional education. Explore the way and method of organic integration of Road and Bridge professional competitions, inventions and creations, and social practices. The assessment and evaluation of innovation and entrepreneurship education is integrated into the assessment and evaluation of professional curriculums, and the matching assessment and evaluation rules and implementation schemes of undergraduates majoring in Road and Bridge are explored.

Through the practice of the integration of Road and Bridge specialty education and innovation and entrepreneurship education, innovation and entrepreneurship education has been integrated into the talent training program, forming a new pattern of "trinity" innovation education, which includes the first classroom, the second classroom and the practice base inside and outside the university, and effectively improving the innovation and entrepreneurship ability of college students. 


\section{SPECIFIC REFORM MEASURES FOR THE INTEGRATION OF CULTIVATION MODELS}

In view of the complementary relationship between innovation and entrepreneurship education and professional education. In order to train innovative and entrepreneurial talents who meet the needs of the economic development of the times, we carry out "school-enterprise full cooperation, class, certificate, competition, integration" talent training mode construction in this major, through relying on a group of school-enterprise cooperation enterprises, serious discussion, careful design, innovation and entrepreneurship education will be integrated into all professional education and learning stages.

\section{A. Construction of "Double Teacher and Double Energy Type" Team and Establishment of "Three Mechanisms" of "One Lesson, Two Blends"}

Most of the teachers of Road and Bridge major in our university come from "from school to school, from students to teachers", although they have rich professional theoretical knowledge, but their practical engineering ability is relatively weak. Therefore, we should fully tap the off-campus practice base resources of this major, making full use of the strong practical ability and the ability to solve practical problems of enterprise engineers and technicians, we should establish and improve the cooperation mechanism with enterprises, explore the establishment of "professional-enterprise teachers' cooperative lesson preparation" mechanism, "professional teachers' site lesson preparation" mechanism and "enterprise teachers' classroom teaching" mechanism, and strive to improve the practical skills of professional course teachers.

Strengthen the construction of "Double teacher and double energy type" teachers in this major, and carry out "in-post" internship for young teachers. The establishment of a "Double teacher and double energy type" teaching staff can not only cultivate students' innovative entrepreneurial thinking, but also have practical innovative entrepreneurial training methods, which can not only impart theoretical knowledge of innovation and entrepreneurship, but also guide students to carry out practical training of innovation and entrepreneurship.

\section{B. Constructing "Modular" Curriculum System}

The thinking of "Mass entrepreneurship and innovation," and "Internet+" has brought great challenges to the entrepreneurial thinking of Road and Bridge majors. Road and Bridge major and innovation and entrepreneurship education should keep pace with the times and adapt to it.

On the basis of professional course teaching outline and revision of the lesson plan, and excavation, enrich the professional courses of innovative entrepreneurship education resources, solid completes the linkage between colleges, according to the requirements of the enterprise technology and the development of the industry, in the teaching into personalized education, according to the needs of the students' individuality and social needs of the industry to integrate the teaching content, increase the students' independent thinking, collaboration, discussion, teaching links such as special summary, training students innovative means and methods.
Carry out the revision of professional talent training program integrating Road and Bridge major with innovation and entrepreneurship education.

By constructing a modular curriculum system of "general education course + dual-creation course + professional course + practical teaching", which is suitable for their own professional characteristics, this paper focuses on the reasonable guidance of college students in this major, and transfers their enthusiasm for innovation and entrepreneurship to the thinking of the Road and Bridge Engineering discipline they have learned.

\section{Strengthening Practical Teaching of Road and Bridge Specialty}

School-enterprise cooperation, strengthen professional practice innovation. Actively expand the government, enterprises, alumni and other resources, build a "two-way, interactive" school-enterprise cooperative operating mechanism, the two sides in personnel training, target positioning, curriculum system, teaching management, practice base, internship, scientific research, student employment and other aspects of good interaction and indepth integration.

Strengthen the innovation and entrepreneurship education and practice base construction of school-local and schoolenterprise cooperation, make full use of the Internet and other resources, invite experts from inside and outside the university to carry out innovation and entrepreneurship exchange and guidance, and build an online and offline innovation and entrepreneurship practice and exchange platform for students.

This measure integrates the competition events, inventions and creations, and social practices of Road and Bridge professionals, and builds a "one lesson, two blends" system suitable for Road and Bridge professionals.

With the continuous application of new technologies, new methods and new materials such as green building materials and Building Information Model (BIM) in the field of Road and Bridge Engineering, the original practical teaching content can be supplemented, re-arranged and screened from the principle of "weakening a batch, highlighting a batch, adding a batch" in the setting of practical teaching events. Nationalprovincial-city-level-university-level" all-round competition competition, to create a good and efficient professional competition "competition package" to encourage teachers and students to actively participate in the above-mentioned competition activities at all levels.

In addition, we should make great efforts to standardize the prominent problems existing in university students' patent application, innovation and invention and related social practice activities, and try to explore the integration of university students' innovation and entrepreneurship activities, patent application and graduation thesis. 


\section{Exploring the Evaluation Criteria of College Students Curriculum Assessment}

The construction of the "one lesson, two blends" system and the continuous strengthening of practical teaching in the major of Road and Bridge inevitably require new requirements for the existing curriculum assessment and evaluation standards for students majoring in Road and Bridge specialties. It can be said that the construction of the "one-lesson-twoblend" system and the reform of the curriculum assessment and evaluation standards for college students are complementary to each other.

The traditional evaluation of college students' curriculum is still based on the "test scores on heroes", Entrepreneurship education for college students in colleges and universities is only to stay on the basis of allowing students to complete the required credits, this is easy to cause college students to have a one-sided understanding of innovation and entrepreneurship education, this situation does not change, will cause most college students to innovation and entrepreneurship education to hold the "credit in hand, business out of hand" mentality, so that the sustainability of innovation and entrepreneurship education and education greatly reduced.

Therefore, it is imperative to integrate the evaluation of innovation and entrepreneurship education into the evaluation of professional courses. For example, the Measures for Credit Evaluation and Accumulation and Conversion of Innovation and Entrepreneurship Practice of College Students in Shenyang University were promulgated. To explore the matching evaluation methods and standards of college students majoring in Road and Bridge. Furthermore, the curriculum assessment with higher requirements for students' practical operation skills and higher integration degree of "one lesson, two blends" in the major of Road and Bridge can be completely replaced by the "competition instead of examination" mode, so as to make the "one lesson, two blends" practically implemented.

\section{CONCLUSIONS}

As a new way of personnel training Innovation and entrepreneurship education has gradually become the focus of higher education and teaching reform. Exploring the way of integration of innovation and entrepreneurship education and professional education has also become an important issue in front of the new engineering specialty. Based on the characteristics of Road and Bridge specialty, this paper seizes the opportunity of application-oriented transformation, constantly reforms and explores the personnel training mode, analyzes how to further cultivate the innovation and entrepreneurship ability of college students, and constructs the integration system of professional education and innovation and entrepreneurship education. In the design of educational concept and personnel training, we should pay attention to the integration of innovation and entrepreneurship education into professional education, and cultivate new talents with innovation and entrepreneurship spirit and ability in a downto-earth way.

\section{ACKNOWLEDGMENT}

Author Introduction: Wei Li(1974-), Female, born in Harbin, Heilongjiang Province, Professor, Director of master, Research interests: Road and Railway Engineering, Innovation and Entrepreneurship Education.

Fund Project: Research Project of Undergraduate Teaching Reform in Liaoning Province in 2018: Exploration and Practice of "One Lesson, Two Blends" System of Transformation and Development of Road, Bridge and River Crossing Engineering Specialty Education in Colleges and Universities.

\section{REFERENCES}

[1] Xuan Yi, Danlin Shen. Exploration on the Integration Model of Entrepreneurship Education and Specialty Education in China's Universities [J]. Journal of Innovation and entrepreneurship education, 2012, 3(2):68-71. (In Chinese).

[2] Haina Huang, Guoqiang Wei, The Practical Dilemma and Effective Ways of Innovation and Entrepreneurship Education in Loca Universities[J]. Journal of Kaifeng Institute of Education, 2016(10):107108. (In Chinese)

[3] Yaxiong Meng, Jiangping Bai, Huajun Wang, Research on the Cultivation of Applied and Innovative Talents based on the Practice Teaching Reform $[\mathrm{J}]$. Journal of Tianshui Normal University, 2016(5):121-125. (In Chinese)

[4] Yin Xiong, Xiaojian Huang, Study on Innovation and Entrepreneurship Education in Local Universities from the Perspective of University Transformation [J]. Student Work, 2018(4):167-168. (In Chinese)

[5] Longqi Li, Junhao Gao, Juanfang Li, Jingyun Liu. Study on the Integration of Innovative Entrepreneur Education and Civil Engineering Professional Education in Universities under Transformation Development[J]. Journal of Hunan Industry Polytechnic, 2018(2):93-95. (In Chinese)

[6] Hua Sun, Xiuping Xie, Research on Talent Cultivation Mode of Organic Integration of Specialty Education and Double-creation Education [J] Journal of Agricultural University of Hebei (Agriculture \& Forestry Education), 2016(10):100-103. (In Chinese) 